\title{
8. How April Salumei Became the REDD Queen
}

COLIN FILER

\section{Introduction}

The Papua New Guinea Forest Authority (PNGFA) maintains a database containing all of the forest areas that have ever been designated as potential logging concessions by means of agreements between their customary owners and the national government or the former colonial administration. In a version of this database that dates to the end of 2011, there are 314 such areas, covering a total of 10,953,897 hectares, which is almost one quarter of PNG's total land area. Most of the agreements had 'expired', which means that the areas in question had almost certainly been logged at some time in the previous 50 years; many were 'current', which means that logging operations were probably ongoing; and a few were under dispute. But one area stands out from all the rest. The 521,500 hectares that comprise the April Salumei forest area in East Sepik Province are the site of the only 'REDD+ Pilot Project' (GPNG 2012a, Appendix 4). This chapter will seek to explain how this particular forest area came to acquire this special status.

Google will tell you many things about April Salumei, but one of the more curious things can be found on a website called 'The Carbon Capture Report', which has a 'profile page' that 'demarks this person as appearing in content suggesting contextual association with Carbon Credits'. The content in question consists of a single post made in August 2011 by a PNG blogger who goes by the name of Masalai — the Tok Pisin term for a bush spirit. The Bush Spirit 
wondered if the carbon tax which had just been introduced by the Australian government would act as a 'catalyst for carbon cowboys' to repeat a form of engagement with PNG's 'carbon credits' which had been the subject of so much controversy back in 2009. Specific reference is made to an Australian company called Carbon Planet as 'the company that would buy and trade the carbon credits that Kirk Roberts was busy quantifying in the forests of April Salumei' (Anon. 2011). It sounds as if poor April may have been an April fool to let that particular 'carbon cowboy' count her carbon credits. And yet she seems to have survived and prospered in the safer hands of government officials.

The Bush Spirit was wrong to suggest that Carbon Planet and Kirk Roberts ever had much to do with April Salumei, but he was right to say that all three of them had figured in a sort of moral panic that enveloped the forest carbon policy process in 2009 (Pearse 2012; see also Wood, Chapter 9, this volume). The origins of this moral panic can be traced back to a political contest that started in 2005, when the prime minister and self-styled grand chief, Sir Michael Somare, made PNG one of the founding members of the Coalition for Rainforest Nations. The aim of this body was to amend the United Nations (UN) Framework Convention on Climate Change in order to enable countries like PNG to receive compensation from the international community for action taken to reduce greenhouse gas emissions from deforestation and forest degradation (REDD). A proposal along these lines was accepted in principle at the UN 11 th Conference of the Parties in December 2005 and has been subject to further negotiation ever since. However, the prospect of REDD compensation payments was not greeted with universal enthusiasm in PNG. That was largely because the Coalition for Rainforest Nations was known to be the brainchild of Kevin Conrad, an American friend of the Somare family who had recently acquired a degree in business administration from Columbia University, and whose previous business ventures in PNG had been somewhat controversial (Lang 2010a).

For a brief period in the middle of 2005, there was an intense but inconclusive public debate about the relationship between Conrad's terms of engagement as PNG's 'climate change ambassador' and the apparent transformation of national forest policy (Filer and Wood 2012: 668). A sense of popular confusion and suspicion in the wake of this debate was expressed in a letter written to one of the national newspapers:

Supposedly carbon swaps means money for the landowners to protect their forest. In reality, our government will give the same ridiculous small percentage to the landowners that they do with any other resource development. The Government will walk away with nearly all the revenue and probably the land rights of the forests ... Next time you see someone promoting carbon swaps, look behind the scenes. Smell the money and find out where most of it goes. (Bamu 2005) 
Although this public debate did not last long, it did foreshadow the more intense debate that came to a head in 2009, in which foreign 'carbon cowboys' were accused of fomenting a 'carbon cargo cult'. Some of the people making these accusations thought Conrad was wholly or partly to blame for this moment of irrational exuberance, yet Conrad deplored it as loudly as they did. As a result, the national government took strong measures to suppress the voluntary carbon schemes which the so-called cowboys were promoting (Filer and Wood 2012: 669-70).

Nearly all of the voluntary schemes have since been thrown into the dustbin of economic history. April Salumei seems to have escaped this fate because she got a stamp of government approval. However, the moment of irrational exuberance was partly fostered by the distribution of these very same stamps to many other projects that have not survived the subsequent rationalisation of forest carbon policy. So there is still a mystery. My attempt to solve this mystery will proceed as follows: in the next section, I show how the idea of a national 'carbon cargo cult' came to be associated with representations of the April Salumei forest area. In the following section, I leave that discourse to one side and recover what is known of negotiations over the development of this area before it came to the attention of the cult's opponents. In the remainder of the chapter, I analyse the social and political process by which the April Salumei REDD project ${ }^{1}$ has achieved a distinctive form of validation at both national and international scales. I conclude with a brief discussion of the reasons for this apparent success.

\section{The Carbon 'Cargo Cult'}

In September 2009, the Weekend Australian newspaper published a feature article by Asia-Pacific editor Rowan Callick under the title: 'The Rush is on for Sky Money: The Struggle Begins to Control the Immense Wealth Certain to Flow from Carbon Trading'. According to Callick (2009), the carbon trade in PNG 'has been converted into a cargo cult luring cash from Australian taxpayers, international investors and local villagers alike'. The Tok Pisin phrase mani bilong skai ('sky money') was said to have been coined as a reference to the profits to be made from the sale of carbon emissions, and reference to a 'cargo cult' was partly justified by evidence that some local villagers had already given real money to 'local confidence tricksters [who] have been trawling through rural

\footnotetext{
1 Although it has been described as a 'REDD+' project, the plus sign is superfluous. The 'plus' was added to REDD at the Copenhagen climate change conference in 2009 to indicate the possibility of securing carbon credits by making forest management more 'sustainable' or planting new forests (see Gabriel, Chapter 10, this volume). The April Salumei project conforms to the older definition of a REDD project as one that simply aims to prevent deforestation and/or forest degradation.
} 
areas, urging people to register with their fake firms to make millions of kina from trading to developed countries the carbon values embedded in their trees' (ibid.). The main source for the whole story was Ilya Gridneff, the Australian Associated Press correspondent in Port Moresby, who was listed as the second author when the story was reproduced in the Post-Courier newspaper (Callick and Gridneff 2009). Gridneff had already published an article in The National newspaper in June 2009 in which he cited David Melick of the World Wide Fund for Nature (WWF) as his own source of information for the popular belief that 'sky money' could be obtained by capturing carbon emissions and bringing them for sale in the national capital (Gridneff 2009a). The implication was that villagers had got the wrong end of the stick when hearing someone talk about technologies for carbon capture and storage.

In June 2008, David Melick was already writing about 'carbon cowboys' as '[u]nscrupulous carbon traders (linked to highly placed political figures)' who were 'strong-arming and threatening landowners' in a manner already familiar in a national forestry sector 'where corruption is rife' (Melick 2008). However, a full year passed before the internet was suddenly abuzz with evidence of strange dealings between some of these carbon traders and Theo Yasause, then executive director of PNG's Office of Climate Change (OCC). ${ }^{2}$ In November 2008, an editorial in the Post-Courier warned of a possible invasion of 'speculators' and 'carpetbaggers' looking to make a fast buck out of the carbon business (Anon. 2008), but most of the local news in 2008 was about the role of the national government and other stakeholders in the design of an institutional framework that would enable respectable foreign investors (including the governments of countries like Australia and Norway) to pay for the conservation of forest carbon. That sort of news did not make for sexy headlines around the world. The media feeding frenzy only started in June 2009, with a stream of articles and blogposts from a number of journalists - most notably Natasha Loder, an American journalist who was writing articles for The Economist magazine, and the aforementioned Ilya Gridneff, who developed a close working relationship with Loder from his base in Port Moresby. In November 2009, Loder and Gridneff were jointly awarded a prize for their efforts by the UN Correspondents Association, but they had run out of scandalous revelations by the end of September, so the story of PNG's 'carbon cowboys' was almost entirely assembled and disseminated over a period of four months.

What the journalists discovered in June 2009 was a set of documents which appeared to show that Theo Yasause had been granting or selling rights to trade in the carbon contained in various forested areas, facilitating deals between

2 This body was initially known as the Office of Climate Change and Carbon Trade, then as the Office of Climate Change and Environmental Sustainability, and more recently as the Office of Climate Change and Development. In this chapter I refer to all its incarnations by the abbreviated title. 
carbon trading companies of different size and provenance, or endorsing the allocation of carbon trading rights that had been made by a government minister back in 2005 - more than three years before the OCC was formally established in September 2008. In July 2009, leader of the opposition Mekere Morauta made a speech to parliament in which he quoted from a letter supposedly written by then minister for trade and industry, Paul Tiensten, to a company called Climate Assist (PNG) Ltd in October 2005, appointing that company as 'brokers on behalf of the Independent State of PNG to buy and sell carbon credits' (Morauta 2009). Morauta would later say that he had come across another letter, sent from the acting secretary for trade and industry to the chief executive director of the same company in June 2005, which confirmed the national government's acceptance of a payment of US $\$ 200$ million in return for '33,333,333 metric tones' [sic] of carbon credits to be traded in accordance with various provisions of the Kyoto Protocol (Talu 2009). In his parliamentary statement, Morauta said that a search of Australian company records had revealed that Climate Assist (PNG) Ltd was 'a one dollar company' based in Queensland, which had since entered into an arrangement with another company called Earth Sky Ltd, registered in the British Virgin Islands, to advance A $\$ 10$ million to the OCC 'in return for the rights to sell $\$ 500$ million carbon offsets, retaining $20 \%$ for themselves'. He also wondered how the OCC had 'authorised a Swiss based broker, South Pole Carbon Asset Management to market 1 million tonnes of avoided carbon dioxide emission[s] per annum from a PNG logging project based in the Sepik, April Salome'.

Some journalists had already made a link between April Salumei, South Pole and Earth Sky (Wynn and Creagh 2009), and another opposition member of parliament (MP) had called for an investigation of the deal between OCC, Earth Sky and Climate Assist at the very start of the media feeding frenzy (Anon. 2009a). The link between all five entities was present in the first draft of a design document, produced in December 2008, for the April Salome Sustainable Forest Management Project (ASSFMP). This contained a copy of a memorandum from Theo Yasause to the prime minister, apparently written in June 2008, on the subject of 'Collaboration with Earth Sky and Climate

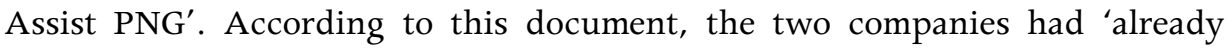
made representation to the National Forest Authority, the Department of Trade \& Industry, National Planning and various land groups in Central, Madang, Morobe, Milne Bay, New Ireland, Eastern Highlands, Western Highlands and Southern Highlands'. It went on to say that they would now be 'remitting close to US $\$ 50$ million per month to the Office of Climate Change to cover for projects in the country for the preservation of loggable forest' in return for 'a certificate to go out and sell the credits' (Earthsky 2008: 31). As part of this deal, the two companies would retain 5 per cent of the revenues from such sales, the OCC 
would retain 20 per cent, 20 per cent would be paid directly to landowners, 15 per cent would be spent on 'community projects', 20 per cent would be placed in a 'future generation fund', and 20 per cent would be turned into a bond 'to cover for forest degradation'. Yasause estimated that REDD projects in eight provinces would 'account for 33 million metric tones of carbon credit', which 'could bring to the country close to $\$ 500$ million US dollars over the next three years'. In order to set this ball rolling, the 'above group' was apparently prepared to invest A $\$ 10$ million in the establishment of the OCC itself (Lang 2009a; Leggett and Lovell 2012: 122).

The mention of '33 million metric tones' - which one imagines to mean tonnes - can hardly be a coincidental echo of the earlier letter mentioned in Morauta's speech to parliament. But the link to April Salumei (or Salome) is rather more tenuous, because East Sepik Province is not one of the eight provinces from which this weight of carbon credits was meant to be derived. The link was only made by inclusion of a copy of the memorandum in the project design document which named Earthsky Ltd as the 'owner' of the project and South Pole as the 'carbon asset manager' (Earthsky 2008: 15). In his own response to the glare of negative publicity which enveloped his office in June 2009, Yasause declared that he had stopped dealing with Climate Assist in September 2008, but the prime minister, the forests minister and the local MP 'have been kept fully informed and involved and are fully supportive of the April Salome Project' (Anon. 2009b). The other potential supporter he failed to mention was Kevin Conrad, who had taken a high-powered Norwegian government delegation on a visit to April Salumei in May 2008.

The glare of negative publicity was not the coincidental result of some brilliant homework by a small group of investigative journalists. The diet of dodgy documents that fed the media feeding frenzy was served up by a group of national political actors who thought that a well-aimed attack on Theo Yasause would bring down the whole house of cards constructed by Kevin Conrad (Lang 2009 b). But they were disappointed. Yasause was suspended and later dismissed, but Conrad's grip on forest carbon policy was not relaxed as a result. He soon announced his own determination to rein in the "carbon cowboys ... [who were] confusing forest communities with tall tales of gold trains just around the corner' (Gridneff 2009b). Whatever he had in mind when he showed April Salumei to the Norwegian government, his new campaign against the carbon cowboys was justified by his previous insistence on the need for a 'national' approach to REDD, not for the state-sponsored 'project-based' approach authorised by Yasause or the purely voluntary version of that approach favoured by some of the non-governmental conservation organisations (Howes 2009; Filer and Wood 2012). This was made evident in a media release that Conrad most likely wrote for his patron, the prime minister, in which it was announced that 'my Government 
does not currently see a role for Voluntary Carbon Agreements in its policy development and regulatory framework for forest carbon and climate change in general' (Somare 2009). The secretary for environment and conservation, Wari Iamo, who had been put in charge of the OCC while Yasause's actions were being officially investigated, later published another public notice pointing out that '[c]arbon trading agreements cannot legally be signed' over land subject to a Forest Management Agreement (FMA) 'until the Government has put in place an appropriate policy and legal framework' (OCCES 2009). The moment of irrational exuberance was officially dead.

\section{April in Waiting}

According to one estimate, more than 90 carbon trading schemes were promoted during that brief period of history, with a combined coverage of more than 5 million hectares of forested land (Melick 2010: 360). Most of the schemes have never been identified in the mass media or in the substrate of grey literature from which the journalists drew most of their inspiration. April Salumei was a very large area of land containing a large amount of unlogged forest, but what really set her apart from the crowd was not so much her physical attributes as her peculiar political history. The PNGFA thought it had acquired the timber harvesting rights from the customary owners by means of an FMA, but the status of this transaction was shrouded in uncertainty. She looked like a REDD project in waiting because forestry officials could not think of a way to turn her into a normal logging concession (Filer 2012: 612).

In March 1992, the former Department of Forests signed a Timber Rights Purchase agreement over the April Salumei forest area with 116 'clan agents' appointed to represent the customary landowners, but 41 of the signatories represented Sepik River communities outside the prospective logging concession "who were supposed to share benefits because of "disturbance" of the river by logging activities' (GPNG 2001: 6). Whether for this or other reasons, the validity of the agreement was challenged in court, so the National Forest Board decided to negotiate a new FMA with the customary owners under the provisions of the new Forestry Act, which had come into effect in June 1992 and turned the Department of Forests into the PNGFA. Following the provisions of the new legislation, officers of the National Forest Service then arranged for the incorporation of 164 (or possibly 181) land groups to represent the customary landowners, and in December 1996 the chairmen of 129 (or possibly 133) of these land groups signed an FMA with the PNGFA (GPNG 2001: 6, 2009: 4028; Leggett 2009: 45). 
In the meantime, a consortium of environmental non-governmental organisations (NGOs) known as Friends of the Sepik had been working with the East Sepik Council of Women and a number of local villagers to oppose the prospect of a large-scale logging operation and opt for an integrated conservation and development project instead (Duguman 2004: 3). In 1995, the World Wide Fund for Nature (WWF) took the lead in helping the dissident landowners to get their land excluded from the FMA area and persuade the Department of Environment and Conservation to recognise it as a Wildlife Management Area (WMA) under the provisions of the Fauna (Protection and Control) Act. An area of roughly 230,000 hectares was duly gazetted as the Hunstein Range WMA in November 1997 (Leggett 2009: 46). Some parts of the new WMA lay outside the boundaries of the April Salumei forest area, but an area of roughly 180,000 hectares was covered by both agreements (Figure 8.1).

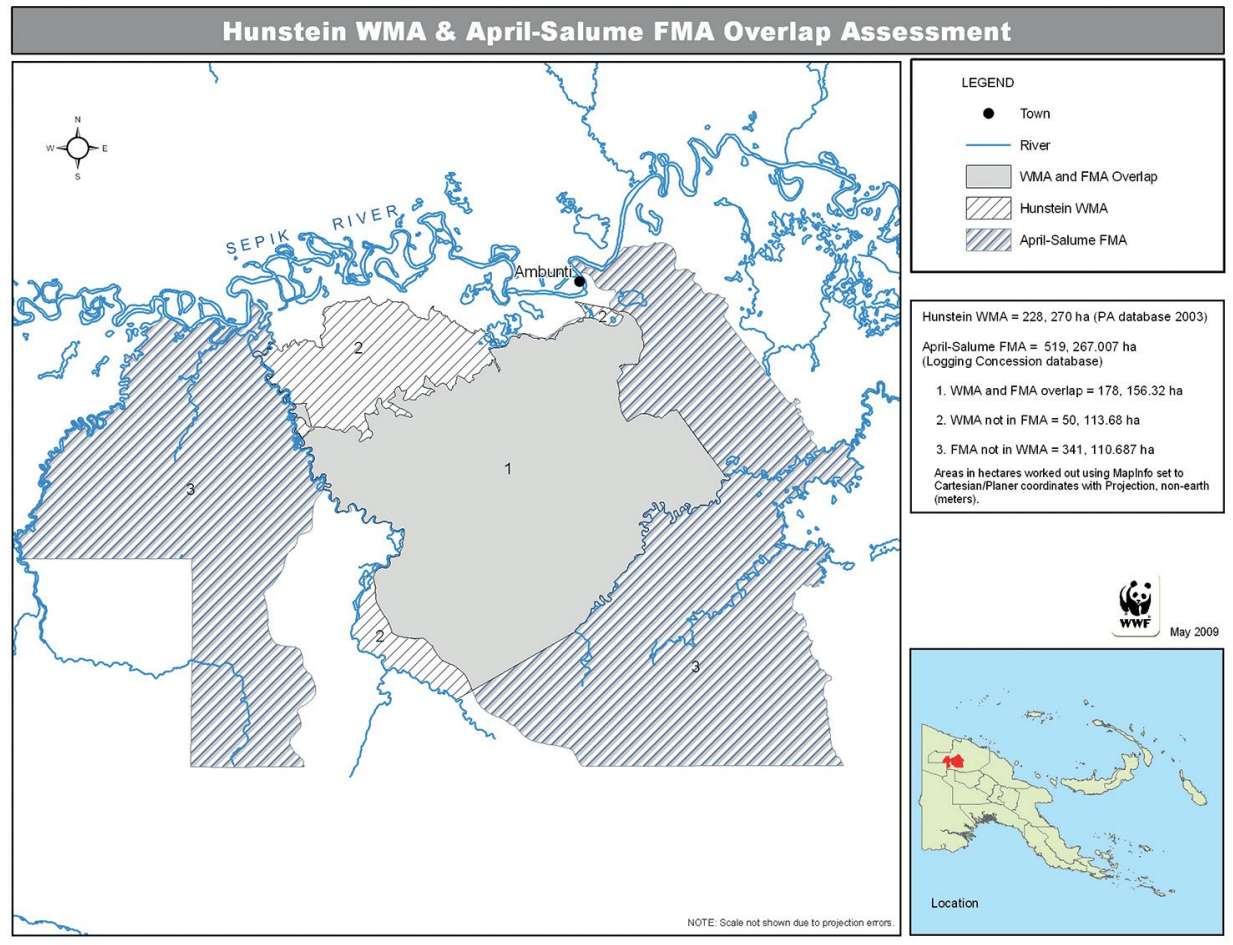

Figure 8.1 The spaces at stake in the April Salumei area.

Source: Map courtesy of WWF, Western Melanesia Program. 
This now became a test case in the relationship between logging concessions and protected areas, and also a test of the relationship between the two government agencies responsible for such things. In an unprecedented gesture of goodwill, the PNGFA 'gave' K40,000 to the Department of Environment and Conservation to conduct an environmental assessment of the FMA area (GPNG 2009: 4025), and this was duly presented to the National Forest Board in February 1999, with the observation that 44 per cent of the forest was 'fragile', and a polite recommendation that logging should be avoided if possible (GPNG 2001: 3). The board was not legally obliged to accept this recommendation, since the declaration of a WMA does not transfer any property rights from customary landowners to the state, but since the PNGFA already knew that a number of landowner representatives had not given their consent to the state's acquisition of the timber harvesting rights, nothing more was done to advance the process of 'resource allocation' prescribed by the Forestry Act. In 1998, WWF secured funding from the Netherlands government for the Sepik Community Land Care Project, with a range of activities directed towards the conservation and development of the Hunstein Range WMA. This project should have lasted for six years, but the funding was unexpectedly withdrawn after five years and the project's capital assets were donated to the East Sepik provincial administration (Duguman 2004).

All of the external agencies and organisations that have sought to establish some sort of claim over the resources of the April Salumei area have been baffled by its cultural diversity and political complexity. None of the interested parties has so far been able to produce a definitive list of the villages or census units that contain the local 'landowners', but they all seem to belong to one or other of the local-level government (LLG) council wards whose populations are shown in Table 8.1. Each ward contains between one and three census units. ${ }^{3}$ The residents of these 27 wards speak 13 or 14 languages, most of which were not traditionally spoken outside the area. Most of the village settlements in the area contain less than 200 people, and these local communities were traditionally at war with at least half of the neighbouring communities, even with those that spoke the same language (Leggett 2009: 63). Nor have the institutions of the modern state done much to enlarge the scale of cooperation between them. Different parts of the FMA area overlap the areas represented by three elected members of the national parliament, as well as the four local councils, but 'April Salumei' people constitute a small minority of the people represented in each electorate, and most candidates would not even bother to canvass their votes.

$3 \quad$ Leggett and Lovell (2012: 123) have published a map showing the local government boundaries and distribution of census units in the area covered by Figure 8.1, but the level of detail makes it hard to decipher. 
Table 8.1 Populations of council wards containing customary owners of the April Salumei forest area in 2000.

\begin{tabular}{|l|r|l|r|}
\hline Tunap-Hunstein LLG area & Ambunti LLG area \\
\hline Walio & 132 & Kupkain & 318 \\
\hline Nein & 117 & Prukunawi & 243 \\
\hline Wusok & 29 & Malu & 661 \\
\hline Wasuware & 25 & Yerakai & 432 \\
\hline Sio & 200 & Garamambu & 621 \\
\hline Hanasi & 166 & Subtotal & $\mathbf{2 2 7 5}$ \\
\hline Moropote & 298 & \multicolumn{2}{|}{} \\
\hline Maposi & 201 & Gawi LLG area & 208 \\
\hline Lariaso & 66 & Changriman & 163 \\
\hline Yabatawe & 144 & Mari & 233 \\
\hline Sowano & 252 & Yembiyembi & $\mathbf{6 0 4}$ \\
\hline Bitara & 192 & Subtotal & \\
\hline Kagiru & 161 & & 443 \\
\hline Begapuki & 179 & Karawari LLG area & 316 \\
\hline Gahom & 134 & Meska & $\mathbf{7 5 9}$ \\
\hline Wagu & 474 & Bisorio & $\mathbf{6 8 9 7}$ \\
\hline Niksek & 489 & Subtotal & \\
\hline Subtotal & $\mathbf{3 2 5 9}$ & \multicolumn{2}{|}{} \\
\hline Total population of wards in all four LLG areas & \\
\hline Sourc: PNG & \multicolumn{3}{|l}{} \\
\hline
\end{tabular}

Source: PNG national census data.

The political fragmentation of the area has been reflected in the multiplication of bodies claiming to represent the rights and interests of the customary landowners. A survey of six villages in the area indicated the presence of 53 'principal clans', of which only 24 had been given legal recognition as incorporated land groups (ILGs) (Leggett 2009: 62), but anthropologists who have worked in this part of the country doubt whether 'clans' actually function as the holders of collective property rights in any meaningful sense (Guddemi 1997). At the time when the FMA was being negotiated with the leaders of those 'clans' that had been incorporated, there were apparently three landowner companies claiming to represent the interests of those landowners who preferred logging to conservation, but shortly after the agreement had been signed, five such companies apparently agreed to form an 'umbrella company' called April Salumei Resource Development Corporation Ltd (GPNG 2001). It is not clear what purpose any of these companies was meant to serve, since the Forestry Act does not recognise landowner companies as legitimate parties to an FMA. On the other hand, some of the land group chairmen who signed over 'their' timber harvesting rights to the state in 1996 were among the landowner representatives 
who teamed up with members of the April-Salumei Landowners Association to support the declaration of a protected area one year later (Leggett 2009: 46). A subsequent review of the FMA summed up the state of confusion as follows:

It is not clear as to which ILGs 'belong' to which LANCO [landowner company]; which ILGs have signed up for forestry and which are working with WWF on non-logging use of the forests; did the April people stay out of the FMA for ethnic or conservation reasons; which ILGs that have signed the FMA are now wanting to withdraw; are the forest owning ILGs happy to have the river ILGs in the FMA since the latter own no forest? (GPNG 2001: 8)

This also helps to explain the National Forest Board's decision not to tender the concession.

This decision was subsequently contested by Hunstein Range Holdings Ltd (HRH), which was one of the landowner companies involved in the previous rounds of negotiation. Jackson Yagi, the chairman of this company, hails from Yerakai village in the north-eastern corner of the FMA, beyond the border of the WMA which sat on top of it (Figure 8.1). Yagi has claimed that HRH was first incorporated in 1995, and that its shareholders were the 129 land groups whose chairmen (including himself) agreed to sign the FMA in 1996 (GPNG 2009: 4033). This claim seems to be at odds with PNGFA records, but those records do suggest that HRH was promoting the interests of one particular logging company as the 'preferred developer' of the area (GPNG 2001). When the National Forest Board expressed its own preference for the area not to be logged at all, $\mathrm{HRH}$ sued the state for the costs it had incurred in its own private dealings.

The outcome of this action would still be shrouded in mystery if it were not for the fact that Yagi and two of his legal advisers later testified before a commission of inquiry investigating allegations of malfeasance in PNG's Department of Finance. According to this testimony, the state agreed to pay K930,100 in compensation to $\mathrm{HRH}$, and K430,000 was in fact paid out in 2005, while another cheque for K380,000, originally issued in April 2008, had 'gone stale' by July 2009 because the solicitor general refused to approve the payment until the commission dealt with the case (GPNG 2009: 4041). In response to questions about the basis of his claim, Yagi said that his board had incurred a lot of travel and accommodation expenses for which it had been obliged to take out something 'like a loan' for 'just over a million kina' from a Taiwanese company called Raw Timber Ltd (ibid.: 4038). He then went on to say that the money received to date had not been used to repay this debt because HRH had incurred more expenses on its own account (ibid.: 4048), and 'today I have taken out another order which the National Court actually granted which was in favour of my landowner company for the entire contract agreement so it has gone up to some 60 million' (ibid.: 4050). However, in a newspaper article published on the day of the hearing, Yagi was reported as saying that he wanted the commission 
to 'fast track' the payment of money under the previous settlement 'to save the State paying K50.8 million as benefits estimated under the Forest Management Agreement' (Anon. 2009c).

Jackson Yagi's interest in the opportunity costs of forest conservation had already been matched by a parallel interest in its potential benefits. In January 2004, he was congratulated by his local MP, Tony Aimo, for establishing a body known as the Hunstein Range Resource Foundation which aimed to acquire one or both of the buildings in Ambunti station which WWF had bequeathed to the provincial government. Aimo was quoted as saying that:

I used to think that the forest conservation programme was purely conservation, but that is not true ... it is about sustainable development of the forest resource and protection of fragile biological resources, and the empowerment of local resource owners with World Bank funding support ... I now call on the National Government and Treasury Minister to immediately conclude all agreements with the World Bank on the forest conservation program so my people can move on with the development of the April-Salumei FMA. (Anon. 2004)

The 'World Bank funding support' to which Aimo made reference would have been money earmarked by the Global Environment Facility for the Mama Graun Conservation Trust Fund as part of a 'forestry and conservation project' which was still being negotiated with the PNG government and which never actually eventuated. The trust's chairman responded to this piece of news by saying that he and his board had yet to seek or receive project proposals from anywhere in PNG, and had certainly not committed any funds to an April Salumei project (Power 2004).

\section{The Springs of Awareness}

The earliest document I have sighted in which the April Salumei area is clearly designated as the site of a possible REDD project is a letter from Theo Yasause to Jackson Yagi that was written in September 2008. In this letter Yasause said:

I am in receipt of your landowner resolutions empowering both you and me to act on behalf of the Landowners to produce and sell carbon credits in the Forest Management Area ... I hereby accept the responsibility as Designated National Authority (DNA) and will assist you with identifying an investor, in particular Earth Sky Ltd, a Company who is partnering the DNA Office to assist with this funding package.

In November 2008, Yasause issued a statement in which he said that 'Papua New Guinea recognizes and supports the April Salome Project as a Voluntary Emissions Reduction project (VER) and confirms that it meets the Sustainable 
Development Objectives of Papua New Guinea'. Later that month, it seems that Yasause received a letter from Prime Minister Michael Somare, in which the latter said:

I make reference to series of meetings with Hustein [sic] Range Landowners and Chairman and Director of April Salome Forest Management Area (FMA) project who have been waiting for payments for eco-system services since the initial discussion in $1996 \ldots$... The landowners have since pursued two parallel processes to either sell their carbon credits or to undertake logging themselves which they are legally entitled to do which would deforest the area for sale of logs. They have this legal entitlement since 1996 but have voluntarily not acted despite entering into a legal case in 1998 and subsequently winning the case in 2007.

Copies of all three documents were included in the same project design document that featured the earlier memorandum to the prime minister on the subject of 'Collaboration with Earth Sky and Climate Assist PNG' (Earthsky 2008). The aim of the whole exercise was to show how the ASSFMP could be recognised as a genuine REDD project by the custodians of two international standards known as the Voluntary Carbon Standard and the Community, Climate and Biodiversity Standard.

It is hard to tell when Jackson Yagi first started to discuss the ASSFMP with Theo Yasause and representatives of Earthsky Ltd and South Pole Carbon Asset Management Ltd. In December 2008, the ASSFMP proposal claimed that scientists at the University of Papua New Guinea (UPNG) were already developing an estimate of carbon stocks in the April Salumei area (Earthsky 2008: 7). In April 2009, a stakeholder consultation process was initiated at a meeting between Yasause, Yagi, and one of UPNG's senior professors, Chalapan Kaluwin (Chem-Clean et al.: 2009: 43). The consultation process hinged on a series of four meetings held in May that year - the first at the aptly named Sepik Center of Hope in Wewak, the capital of East Sepik Province, and the rest in three of the villages in the April Salumei area. Each meeting seems to have lasted around three hours and involved an exchange of views between local stakeholders and representatives of a national company called Chem-Clean Ltd. UPNG staff and representatives of South Pole were party to the process of organising and recording these exchanges. Chem-Clean submitted draft minutes of the four meetings to the OCC within a fortnight of conducting them (ChemClean 2009), but the South Pole people were clearly dissatisfied with the way in which responses to local people's questions had been represented in this document. As a result, they compiled a second report which included a running commentary on the validity of responses offered by the Chem-Clean consultants and a record of subsequent written exchanges with other stakeholders, including WWF personnel (Chem-Clean et al. 2009). This second report seems to have been completed around the end of July 2009. 
The likelihood of distorted communication at the four consultation meetings may be inferred from the text of the public notice which advertised their subject matter. For example, the English-language text of the notice which appeared in a national newspaper said that '[l]eakage effects will be addressed by supporting sustainable plantations and an[y] remaining leakage will be addressed by an econometric analysis of supply elasticity, leading to a conservative adjustment of emission reductions' - a statement which understandably failed the translation test in the Tok Pisin version on the bottom half of the page (OCCCT 2009). ChemClean's own minutes record some of the distortions that actually took place. For example, at the meeting in Wewak:

One audience member was asking 'What are other risks or bad things from Carbon trade after talking about good things?' This shows that people are still ill informed about issues on climate change and carbon trade. Anyway, we manage to explain to the crowd the negatives or risks of carbon trade such as leakages, additionality, permanence, contractual obligations, slicing of credits because of deforestation, socio-economic impacts, fluctuations of carbon prices in the stock markets etc. (Chem-Clean 2009: 6)

A question posed in one of the village meetings elicited an equally puzzling response:

'What are the penalties for non-compliance to legal agreement?' We responded that the buyer can slice our revenue if there is deforestation. They have to be responsible for their act and do the right things to protect their environment and forests. They can educate their children and make proper land-use plans or even ask the developer to included [sic] buffers that can offset any leakages, additionalties [sic] and permanence. (ibid.: 16)

Given that most of the village conversations were conducted in Tok Pisin, it is hard to imagine what was actually said here, let alone what was understood. It is doubtful whether any of the local villagers would have ended up with a better understanding of the relationship between land-use plans and the technicalities of carbon sequestration in light of the Tok Pisin version of the following conversation in another village meeting:

A landowner was concerned that they have a WMA within the FMA area of 520,000 ha. The 126,000 currently and its carbon credits of 2.2 million GtCO2e is too small. He was concern [sic] that if the 126,000 ha does include both the WMA and FMA. We elaborated that under REDD, the 200,000ha of WMA is not qualified because it was already 'protected'. This means only the FMA area of 520,000 ha is eligible. However, we mentioned that since the WMA is inside the FMA area and there are still legal issues between PNG Forest Authority and the Department of Environment and [C]onservation, REDD may be the only solutions to both problems and could be easily resolved. Hence, the landowner urged the government to consider the 520,000 ha a REDD project to avoid confusion. (ibid.: 8-9) 
Even the second report on the consultation process failed to clarify the physical extent of the area from which carbon credits would be extracted.

The additions made by the South Pole people to the second report were less concerned with the quantification of leakage, additionality and permanence than with the question of how REDD project revenues would be distributed. When someone 'in the crowd' at the Wewak meeting asked about 'benefit sharing mechanisms', the Chem-Clean consultants apparently said that they had 'no idea', and referred the question to the HRH representative, who 'stated that they will get over $60 \%$ whilst the rest will go to the government and the developer' (Chem-Clean 2009: 7). It is not clear from the draft minutes whether 'they' would be the landowners or the HRH directors, so members of 'the crowd' might have been forgiven for concluding that the landowners would get nothing at all. As for the 'developer', the consultants told the people present at one of the village meetings that ' $2.2 \mathrm{GtCO} 2 \mathrm{e}$ was already sold to Earthsky' (ibid.: 9). This prompted a 'landowner company representative' to allege that 'some money valued at USD25 million was already misused by the government when Earthsky [was] already paid upfront', and then go on to say that bank statements were now being collected 'to justify and validate their claim' (ibid.: 10).

At this juncture, the South Pole people added a note to the second report to say that they did not think Earthsky had so far made any payments to the PNG government. This note immediately went on to say that all of the revenues from the sale of carbon credits would accrue to a body called the April Salome Foundation (ASF), which would spend 80 per cent of the money on projects in the FMA area, 18 per cent on other projects, and would contribute the remaining 2 per cent to the UN Central Emergency Response Fund (Chem-Clean et al. 2009: 20). The second report alluded to an 'organisational chart' which represents this form of benefit distribution (ibid.: 16), and although this chart is not attached to the report itself, it was reproduced in a thesis written by Matthew Leggett, who conducted fieldwork in the April Salumei area between May and July 2009 under the auspices of WWF (Leggett 2009: 52). The chart is at variance with the note, for it shows that gross revenues from the sale of carbon credits would accrue to Earthsky, which would then subtract an unspecified amount to cover its own costs and the costs associated with provision of 'technical support' to HRH. The ASF would then receive 80 per cent (not 100 per cent) of the net revenues, and would spend this money on projects proposed by the ILGs holding shares in $\mathrm{HRH}$, while 18 per cent would be paid to the PNG government (not the ASF) as a sort of tax to cover the cost of 'projects' outside the April Salumei area. Leggett's investigation of the ASF website (which no longer exists) raised a suspicion that $\mathrm{HRH}$ directors might be involved in the management of that body, 'which if correct would represent a clear conflict of interest' (ibid.: 53). 
In light of all these conjectures, it is hard not to sympathise with a woman who was said to have become 'emotional' at one of the Chem-Clean village meetings, wanting the government to 'realise that many men in Port Moresby cheat us', while insisting that the villagers themselves 'have all the resources and we are not stupid'. The consultants took this to mean that 'the villagers are happy in their [villages] though they lack basic government services and infrastructures' (Chem-Clean 2009: 13).

Happy or otherwise, there was evidence in Chem-Clean's draft minutes that local villagers had some rather odd ideas about the carbon trade. One villager was reported to have said that 'things such as sicknesses, deaths of trees caused by bad gases, remove [sic] of good air from their forests have created panic and false alarm among people' (Chem-Clean 2009: 9), while another reportedly said that 'we thought a tower will be build [sic] to capture all bad gases and these gases will be packed and sold for cash' (ibid.: 14). Leggett's subsequent research in the area found that Chem-Clean's consultants had failed to dispel such ideas, and might well have encouraged their diffusion. Local knowledge was now encapsulated in the idea that transactions in forest carbon involved the 'work of selling air' (wok bilong selim win) or else the collection of 'sky money' (mani bilong skai) (Leggett 2009: 56). Two of his informants asked questions in Tok Pisin which Leggett translated as follows: ${ }^{4}$

What kind of pipes or other things do we need to collect the carbon? Will this company South Pole come here and build a factory to collect the carbon? Or do we need to collect it in plastic bags and go to Wewak or what? We don't understand. It sounds like hard work ...

Where does this wind (carbon) come from? It comes from the ground and the forest belonging to us. If South Pole come here and destroy our forest and our resources and steal our air I'm really worried. If they eat up our air, our children are going to die — what will they breathe? (Leggett 2009: 57).

The second report on the consultation process took due note of Leggett's findings, and concluded that 'key challenges such as the legitimacy of representation by the landowner company, details on benefits and equity sharing, transparency, accountability, general information on carbon markets and current and future land use issues will have to be addressed to ensure a proper sustainable implementation of the project' (Chem-Clean et al. 2009: 37). 


\section{Survival of the Fittest}

In the wake of all the scandal about carbon cowboys and the carbon cargo cult, there was a notable decline in the number of foreign companies willing to invest any more time or money in the development and promotion of REDD projects in PNG. Earthsky, South Pole and Carbon Planet were three of the companies that vanished from the national scene at this juncture. Nevertheless, a company called Rainforest Project Management Ltd (RPM) took on the role of developing the April Salumei Sustainable Forest Management Project — with April's name correctly spelt. ${ }^{5}$ The ASSFMP proposal was submitted to the Climate, Community and Biodiversity Alliance (CCBA) in June 2010, and its validation was approved one year later.

The 2010 version of the ASSFMP proposal had no individual authors, but listed a number of 'project development partners', including $\mathrm{HRH}$, the Prime Minister's Department, the OCC, the PNG Forest Research Institute (a branch of the PNGFA), and the UPNG Centre for Climate Change and Sustainable Development (RPM 2010: 7). The document was not only posted to the CCBA website, but also to the website of a body called the Rainforest Management Alliance, a body that seems to have been created by the ASSFMP's 'project manager', Stephen Hooper, who also represents the 'project implementer', RPM. The Rainforest Management Alliance website featured four other proposals for carbon trading projects in PNG (and none for projects in any other country), but there is no evidence that any of the other four proposals were ever submitted to the CCBA. The space occupied by the ASSFMP proposal also came to feature some additional documentation: a letter of support apparently written by the prime minister's legal adviser to the local MP, Tony Aimo, in July 2010; another one seemingly written by the government's acting chief secretary to Stephen Hooper himself in August 2010; two undated press releases in favour of the project from Tony Aimo and the forests minister, Belden Namah; and a copy of the Ambunti-Dreikikir District Development Plan (in which the project was not mentioned). ${ }^{6}$

The 2010 version of the project proposal claimed that a new round of meetings had been held with local community members and the chairmen of local land groups and landowner companies between October 2009 and January 2010, as a result of which 163 land group chairmen had supposedly signed consent forms (RPM 2010: 96). The local landowners were now said to be divided between

5 Earthsky's disappearance from April Salumei was more apparent than real, because RPM turned out to have the same registered address in the British Virgin Islands.

6 The Ambunti-Dreikikir district or electorate is the one that has been represented in parliament by Tony Aimo between 2002 and 2013. It includes the Ambunti and Tunap-Hunstein LLG areas, and thus includes about 80 per cent of the people with customary rights in the April Salumei forest area. 
'four main cultural groups', each with a specified number of ILGs holding shares in a different landowner company, and these four companies were said to be shareholders in HRH (ibid.: 24). The land groups whose chairmen refused to sign the original FMA were now said to be among the 44 land groups that had agreed to let one of the four landowner companies (Niksek Samsai Resources Ltd) act on their behalf. Information about the social, economic and political organisation of the area seems to have been derived from a report written by a company called Tack Realty Ltd in 2004, but no proper reference is given to this report, nor have I sighted a copy of it. The proposal made provision for another three or four years' work to 'update' land groups and map their boundaries, and 'once it is done it will provide what will be possibly the most robust database and understanding of traditional landownership in PNG' (ibid.: 89).

Tack Realty's earlier investigation of this subject seems to have been commissioned by $\mathrm{HRH}$ as evidence in support of its compensation claims. The ASSFMP proposal cited this report as evidence that the opportunity cost to local landowners of keeping loggers out of the FMA area was more than US\$188 million, and then said that if the landowners were to succeed in their ongoing efforts to secure K58 million in compensation from the national government, this would not entail any relinquishment of their 'logging rights' or their 'right over the biodiversity' of the area (RPM 2010: 39). The proposal used PNGFA figures to determine that the 'gross forest area' covered by the FMA was around 177,000 hectares, and if a 15 per cent 'buffer zone' were to be subtracted from this figure in accordance with the National Forestry Development Guidelines, that would leave a 'net production area' of around 150,000 hectares that would have been logged under a timber permit (ibid.: 63). Nevertheless, it is the larger of these two areas that was described as the 'carbon accounting area' (ibid.: 65), from which all agricultural activity, including the practice of shifting cultivation, would be banned under the terms of the project proposal, so people owning land within this area would henceforth have to make their gardens somewhere else (ibid.: 93). There was a glimmer of recognition that this could cause a problem for the distribution of landowner benefits from the project, because 'the population distribution map shows the population is not evenly distributed and the carbon accounting area to be least populated', but this problem was thought to be solved because 'we have assumed an even distribution to be conservative' (ibid.: 65) - whatever that meant.

By the end of July 2010, the CCBA website contained six comments on this version of the project proposal. These included comments from Theo Yasause (in his private capacity), Wari Iamo (in his official capacity), Matthew Leggett (on behalf of WWF), and Martin Golman, who was the deputy director of the Forest Research Institute. All comments except the one made by Yasause were critical of the proposal. Leggett's comment included a copy of a published press 
release in which Iamo denied that the OCC was a 'project partner' or was ever even approached for its 'endorsement, support or partnership' (OCCD 2010). Iamo's own comment consisted of a letter reiterating a recent decision of the National Executive Council 'that voluntary trading of forest carbon is inadvisable and premature under present arrangements', and attached legal advice to the effect that PNG's laws did not yet allow for the creation of negotiable property rights in forest carbon (CCBA 2010: 31-8). Golman's comment was the longest and most critical of all, possibly because he was, as he said, partly 'representing himself as a prominent landowner of Malu village in the project vicinity and an expert in sustainable forest management practices and carbon assessment in April Salumei' ${ }^{7}$ but also because he had some responsibility for negotiating the FMA with local landowners in 1996 in his capacity as an official of the National Forest Service (ibid.: 9-10). Golman maintained that many of the landowners in the April Salumei area had never consented to being represented by Jackson Yagi and HRH in the negotiation of any project at all, nor had they ever received any share of whatever money HRH had managed to secure by way of 'compensation' from the state for the opportunity costs of forest conservation (ibid.: 13). He went on to propose that any further research relating to forest management in the area of overlap between the FMA and the WMA should be conducted by the Samsai Niksek Forest and Carbon Foundation, founded by himself, in partnership with the Forest Research Institute (ibid.: 18).

\section{The Crowning Moment}

Despite this negative commentary, April Salumei was still crowned as the only pilot REDD project in an area covered by an FMA. The 'validation' of the project was undertaken by a Californian body called Scientific Certification Systems, which contracted a New Zealand company called Environmental Accounting Services Ltd to check the project's compliance with the CCBA's 14 project design standards. The validators did most of their work between June and August 2010. This included an evaluation of the negative comments posted to the CCBA website and the conduct of 'community meetings' at three locations in the FMA area (SCS 2011: 6). Their report contains 41 instances of 'non-conformance' that required some modification of the project design document, but many of these were minor and easily dealt with by the project proponents. Once the project document had been revised to the satisfaction of the auditors, a 'validated copy' was released for public consumption. This time the authors were shown to be Stephen Hooper and a group of seven Papua New Guineans, all of whom had at one time or another been employed by UPNG, although one, Simon Saulei, had

7 He had recently completed a PhD thesis on this topic at The Australian National University. 
returned to his former post as director of the Forest Research Institute at the beginning of 2009. Both documents, along with a 'monitoring plan' requested by the validators, were posted to the CCBA website. ${ }^{8}$ They also appear on the website of another body called the Pacific Forest Alliance, which is also one of Stephen Hooper's creations. ${ }^{9}$

The most significant modifications of the project design to emerge from the validation process were concerned with problems of authorisation and ownership. The first of these problems was to determine which local people had some entitlement to be consulted about the project, or be made aware of it, or give their consent to it, or share in whatever costs and benefits it might generate. The 'carbon accounting area' was now confined to the 'net production area' (around 150,000 hectares) that would be logged if a timber permit were granted over the FMA area (around 520,000 hectares), but the REDD 'project zone' was now expanded beyond the boundary of the FMA area, not only to include a 10-kilometre buffer around its northern, eastern and southern flanks, but to the banks of the Sepik River in the north and to the East Sepik provincial boundary in the south (Hooper et al. 2011: 33). ${ }^{10}$ This meant that it included the whole of the WMA that lay outside the FMA area (Figure 8.1) and probably covered about 900,000 hectares altogether. In the previous design document, the 10-kilometre buffer zone was thought to contain people who might be impacted by the project (RPM 2010: 26), but the validators thought that the 'Project zone boundary should ensure that it encompasses the boundaries of the four land holder companies', and should eliminate the possibility of an ILG land boundary 'extending past the Project boundary' (SCS 2011: 57). In an effort to comply with this peculiar requirement, the proponents now said they would give due consideration to 'traditional boundaries that extend outside the project area and into the project zone', and were apparently prepared to consider the residents of the larger project zone as people who might have use rights, if not ownership rights, within the FMA area (Hooper et al. 2011: 30-1). No attempt was made to count the number of extra people resident in this larger area, ${ }^{11}$ or to demonstrate that they had been made aware of their new situation.

The revised project document did not provide any additional information about the number of people who had traditional rights to make use of the carbon accounting area in ways that might detract from the amount of carbon contained within it, but the former threat of prohibition was replaced with

8 www.climate-standards.org/category/projects/oceania/ (viewed April 2015).

9 www.pacificforestalliance.org/ (viewed April 2015).

10 For some unknown reason, no buffer zone was created on the western banks of the Leonard Schultze River, which constitutes the western boundary of the FMA area.

11 The project proponents have consistently represented the resident population of the FMA area alone as being 7696 in 2000 (RPM 2010: 33; Hooper et al. 2011: 39). In the absence of a detailed breakdown of this figure, I am unable to explain the discrepancy between this number and my own calculation (Table 8.1). 
a risk assessment and mitigation matrix (Hooper et al. 2011: 100-9). The 41 risks evaluated in this section of the document included such things as 'population growth', 'agricultural pressure', 'hunting of endangered or threatened species', 'small scale clearing of land', 'regular burning of grasslands' and 'access to areas fundamental for meeting basic needs of the local community'. But apart from the possible impact of hunting on biodiversity, none of these was considered as problematic as risks like 'ILG leadership struggle', 'lack of knowledge and skills in business administration', 'inappropriate use of funds', 'financial benefits not shared equally', or 'slow delivery of the project'. Most of the risks identified in the matrix would be offset by a mixture of 'awareness and monitoring' activities on the part of local 'community stewards' (ibid.). But the auditors thought that these activities would have to be framed by 'an appropriate methodology for the identification of impacts on the community' (SCS 2011: 66), as well as a 'community monitoring plan' (ibid.: 68). The revised project document therefore includes another new section on social impact indicators that is remarkable mainly for its observation that the biggest impact of the project on the local people is likely to be 'the identification of the true landowners and the subsequent distribution of benefits to them' (ibid.: 158).

In their own process of consultation with local communities, the validators discovered a popular belief that an unequal distribution of benefits to ILGs resulting from the unequal size of their landholdings would probably lead to conflicts that might (or might not) be resolved in many different ways (SCS 2011: C-20). One might imagine further scope for conflict if the distribution of benefits did not match the distribution of customary rights to exploit the natural resources in the carbon accounting area. But Stephen Hooper shied away from the idea that benefits should be matched to impacts or opportunity costs:

It has also been agreed by the landowners and documented in the PDD [that] all funds emanating from the Project will be distributed equally amongst all landowners. That is every man and woman over 16 years of age will share equally. This we believe is a fair system. Payments will be made directly to the Incorporated Land Groups and not through Hunstein Range Holdings.

(SCS 2011: C-7)

The reference to HRH reflects the well-documented local 'awareness' of its previous failure to distribute benefits in an equitable manner (SCS 2011: 11). The statement as a whole implies that this failure would henceforth be compensated by payments of cash to each one of the 163 ILGs whose chairmen consented to the project at the end of 2009, the amounts of which would vary in proportion to the number of their adult male and female members. But aside from a passing reference to compensation payments 'in cash and kind' in the project design document (Hooper et al. 2011: 156), the general presumption was that direct benefits to local communities would take the form of employment 
with the REDD project itself and a set of specific 'social and infrastructure projects' approved by the board of the ASF (ibid.: 118). There is no way the REDD project would produce 163 jobs. A much smaller number of local workers would apparently be employed by one or other of the four new landowner companies (ibid.: 113), and their executives would only achieve a voice on the ASF board through their membership of the HRH board (SCS 2011: B-5).

The validation process failed to clarify the nature of the property rights vested in HRH and the consequent rights of its directors to participate in the REDD project. The validators decided that the project was initially authorised by an agreement between HRH and Earthsky that dated back to May 2009 (SCS 2011:22), and Hooper then agreed to describe Earthsky as the 'project originator', which had appointed RPM to develop and manage the project on its behalf (ibid.: 63). At the same time, the validators said that they agreed with RPM that HRH was 'the current legal entity that has been recognised through the PNGFA and the PNG Supreme Court as having the resource rights to the FMA and are therefore a significant Project stakeholder' (ibid.: B-5). However, there is no evidence that the PNG Supreme Court or any other court had vested these rights in $\mathrm{HRH}$, and any decision along these lines would be totally inconsistent with the Forestry Act, which clearly states that an FMA is an agreement by ILGs - not a landowner company - to transfer timber harvesting rights to the PNGFA.

Jackson Yagi's claim for compensation had been based on the failure of the PNGFA to convert the FMA area into a logging concession from which he and other landowners might derive some material benefit. Hooper himself told the validators that the REDD project was conceived as part of an 'out of court settlement' of this legal dispute (SCS 2011: 72). What was at stake here was not the ownership of the timber resources (or the forest carbon) in the FMA area, but the degree to which the declaration of the Hunstein Range WMA justified the PNGFA's failure to grant a timber permit to a logging company. The circumstances of the settlement are unclear, ${ }^{12}$ but proponents of the REDD project needed to prove that the WMA had been invalidated in order to acquire the magical substance known to the world of carbon trading as 'additionality'. In other words, they had to make a case that the FMA, or more specifically the carbon accounting area, would have been logged in the absence of their project (ibid.: 63-5). If the National Forest Board was to take the existence of the WMA as evidence that some local landowners had never consented to the FMA, and use this as a pretext for not granting a timber permit, there would be

12 According to Leggett (2009: 46), it was the Department of Environment and Conservation that settled the HRH claim in 2007, but a commission of inquiry into the Department of Finance determined that HRH received the first payment in respect of its claim in 2005 (GPNG 2009: 4041). 
no additionality. ${ }^{13}$ Since that was the board's position before Jackson Yagi made his claim against the state, it was essential for the project proponents to award him a victory of some sort (ibid.: 14). But how could that be reconciled with the need to secure the support of all the local landowners? Stephen Hooper had two solutions to this problem. One was to wash his hands of it by refusing to become involved in 'local level politics' and insisting that 'the structure and make up of representative companies must be determined by the people living in the villages on a daily basis' (ibid.: C-4). The other was to make an arrangement for the PNG Electoral Commission to supervise the democratic election of the boards of each of the four - which now became five - new landowner companies within six months of project validation, and to require that each of their boards have two representatives on the board of HRH. ${ }^{14}$ Jackson Yagi told the validators that he was happy with this arrangement (ibid.: 58).

If these measures promised to deliver a new sense of joint ownership among the local landowners, other measures were taken to enlarge the circle of support from national stakeholders. Although WWF representatives declined an invitation to be involved in a further round of community consultation in August 2009, one of the organisation's national employees later took leave from his job to identify gaps in the state of landowner awareness (SCS 2011: C-3). A local NGO, Partners with Melanesians, was engaged to be the project's dispute resolution authority (ibid.: 24), and both organisations were invited to join an independent review body to advise the ASF's board of trustees (ibid.: C-7). Martin Golman's critique, which the validators ascribed to a 'degree of professional jealousy' (ibid.: B-3), was quickly muted when the forests minister, Belden Namah, expressed his own support for the project in August 2010 (ibid.: 64). Although Namah then crossed the floor of parliament to become leader of the opposition, his erstwhile support was sufficient for work on the April Salumei project to be funded in the PNGFA's budget for 2011.

This meant that Wari Iamo and the OCC began to look somewhat isolated in their public denial of support for the project. The validators sought to neutralise this source of opposition by suggesting that Iamo may not have been the executive director of the OCC when he published his adverse advertorial in July 2010 (SCS 2011: 33), while Stephen Hooper argued that the project did not need support from the OCC anyway, so long as it had the backing of the prime minister, the forests minister and the local MP (ibid.: 63). Iamo was certainly the secretary of the Department of Environment and Conservation (DEC), and

13 At one point in their report, the validators seem to have thought that the WMA was still officially recognised but had somehow been excluded from the carbon accounting area (SCS 2011: 73), but there is nothing in the REDD project design document to support this notion.

14 A fifth landowner company was established in September 2010 because of a split between two sets of land groups in the WMA that had formerly been shareholders in Niksek Samsai Resources Ltd (SCS 2011: C-5). 
there was no doubt that he had been appointed as the acting executive director of the OCC when Theo Yasause was suspended, which meant that the OCC had looked like a branch of the DEC since July 2009. If he no longer occupied this extra position in July 2010, then it seems rather strange that he chaired the multi-stakeholder workshop convened in Port Moresby's Hideaway Hotel in February 2011 to endorse the National Programme Document (NPD) (that would release US\$6.4 million from the UN Collaborative Programme to implement the first, three-year phase of PNG's 'REDD+ readiness roadmap' (UN-REDD 2011). The managing director of the PNGFA informed this meeting of his agency's intention to implement the April Salumei project as a pilot project, but he did not chair the meeting, nor was the project mentioned in the NPD.

This was just one moment in an ongoing struggle between the PNGFA and the OCC (or DEC) for control of the forest carbon policy process. Local environmental NGOs made an unaccustomed alliance with national forestry officials in this struggle because they saw the reformed version of the OCC as a puppet of Kevin Conrad and the group of highly paid foreign consultants whom he had introduced to this process immediately after the Copenhagen climate change conference at the end of 2009 (Lang 2010b; Babon 2011; Filer and Wood 2012; Babon et al. 2014). Supporters of the April Salumei project were reluctant to endorse the NPD while there was no prospect of an end to this form of foreign interference. Their wish was granted sooner than they might have expected. In August 2011, Michael Somare was ousted as prime minister. His replacement, Peter $\mathrm{O}^{\prime}$ Neill, appointed Belden Namah as his deputy, restored him to his former portfolio, and put him in charge of the OCC as well as the PNGFA. Shortly after his appointment, Namah announced the dismissal of Kevin Conrad from his position as PNG's climate change ambassador on the grounds that he had little or no knowledge of the 'culture, tradition and lifestyle of the people', and therefore could not deal with 'landowner issues' (Waima 2011). Meanwhile, the foreign consultants had already disappeared because their contracts had expired or their fees had not been paid. Wari Iamo retained his position as acting head of the OCC for the time being, ${ }^{15}$ but ceased his pursuit of the case against April Salumei.

In the months that followed, the project monitoring plan was finalised (PFA 2012), a new study was undertaken to assess the feasibility of attaining compliance with the Voluntary Carbon Standard (Green 2012), and some additional work was done on the measurement of local carbon stocks. For some unknown reason, the Voluntary Carbon Standard Feasibility Assessment added 100,000 hectares to the size of the net forest production area (Green 2012: 5), but it did not

15 Like many other public servants, he resigned from office in March 2012 in order to contest the forthcoming national elections. He was not elected. 
provide any new information about the customary landowners. One interesting feature of this report was the inclusion of a new organisation chart in which the chairmen of the five landowner companies would be members of a new body called the April Salumei Working Group, whose interaction with project management would not be mediated by the board of $\mathrm{HRH}$ (ibid.: 8). It was also stated that local landowners would 'receive a minimum of $60 \%$ of all sale proceeds directly', and that this 'paradigm shift to landowner involvement and payments' had been authorised by the national government. While there was no evidence of any sales proceeding, two motor boats and K200,000 had apparently been delivered to the working group to 'kick start local community activities' (ibid.: 9).

All this happened before the national elections in the middle of 2012. Thereafter, Peter $\mathrm{O}^{\prime}$ Neill retained his position as prime minister, Tony Aimo retained his position as the local MP, while Belden Namah returned to his former role as leader of the opposition. The new minister of forests and climate change was another former forests minister, Patrick Pruaitch. Pruaitch is an ally of Michael Somare, who now became the governor of East Sepik Province and declared his support for the ruling coalition. The National Executive Council reiterated its own endorsement of the ASSFMP in December 2012. To celebrate this moment, Tony Aimo appeared on national television with the chairman of the April Salumei Working Group, the local project manager, and a king-sized replica of a cheque for K300,000 to be divided equally between the five landowner companies. At the same time, Aimo told a national newspaper that April Salumei would be 'the biggest carbon trade project in the world to date' (Anon. 2012b).

\section{Conclusion}

April Salumei is not in fact the only forest carbon project that was still alive in PNG in 2013. The PNGFA claimed to have four other 'REDD+ pilot projects' in the 2012 draft of its National Forest Plan (GPNG 2012a: 18), while five NGOs were said to have received grants from the Australian government to develop 'REDD+ demonstration activity concepts' (Babon 2011: 5). However, April Salumei was the only survivor of the many projects that were being promoted back in 2008, and the only one that seemed to have any prospect of producing marketable carbon credits instead of simply being funded by the national budget or foreign aid. The other projects in the National Forest Plan all involved afforestation or reforestation or reduced impact logging, there was no detail on the activities being undertaken or proposed, and none of them was clearly tied to an area where the government had already acquired the timber harvesting rights without passing them on to a logging company. 
April Salumei's survival in a process of natural selection may have something to do with her physical qualities. Her biodiversity values do not exceed those of any other forest area in PNG, but a good case can be made for them to exceed those of any other FMA area where logging has not yet been authorised. This was a case which WWF made to the government back in 1996, and a case which the REDD project proponents had been making more recently. The CCBA awarded the project a gold medal for 'exceptional biodiversity benefits', but not for exceptional climate or community benefits (SCS 2011: 55; Hooper et al. 2011: 171).

April Salumei's survival also had something to do with her status as a form of property and her claim to the magical power of additionality. The PNGFA was less convinced of its capacity to authorise logging in some of the other FMA areas because the original agreements with local landowners were even more questionable than they were in this case. Could it therefore be argued that the ASSFMP thrived on an exceptional level of local community support or an exceptional ability of external agents to mobilise community participation? There is not enough evidence to evaluate recent interactions between landowner representatives and outsiders like Stephen Hooper, but there is little reason to credit the effort made to produce 'landowner awareness' of the REDD project in 2009. That was surely a false start. If there had been an increase in local understanding and appreciation of the project since that time, the evidence suggests that it was far from being equally distributed among different groups of landowners. It is hard to imagine that a local 'community' that may now contain 5000 adult members (if one includes absentee landowners like Martin Golman) could possibly speak with one voice when they have 13 or 14 vernacular languages. The political, social and cultural fragmentation of the April Salumei area is a huge - and possibly insurmountable - challenge for a comprehensive demonstration of free, prior and informed consent (Anderson 2011; Leggett and Lovell 2012). The recent semblance of consensus may be due to a common but fragile sense of anticipation, which could either break down if the anticipated benefits fail to materialise or break down if they do materialise and are (thought to be) unequally or unfairly distributed.

Perhaps the level of community support has been less significant than the level of support from provincial stakeholders, including the local MP and the former prime minister. Theo Yasause also hailed from East Sepik Province, and there is no doubt that he showed greater enthusiasm for April Salumei than he did for any other REDD project proposal during his time in charge of the OCC. He also had good reason to think that Michael Somare - and therefore Kevin Conrad - would prefer to see PNG's first REDD project developed in their own province. Yasause's own preference no longer matters, but when Somare met the forest-friendly Prince of Wales on the occasion of his mother's diamond jubilee 
in November 2012, Somare proposed to honour the occasion by making East Sepik a REDD 'demonstration province' (Anon. 2012a). Conrad and Pruaitch were both in attendance to welcome this initiative. On the other hand, there is no evidence that April Salumei's most active supporters made an effort to get Somare's stamp of approval — let alone that of Conrad or the Prince - after Yasause was removed from office in 2009.

I think a stronger case can be made for the importance of support from a group of national stakeholders who are members of what I call the 'conservation policy community' (Filer 2005). As we have seen, the original members of this group were based at UPNG in 2008, but membership later expanded to include people employed in the Forest Research Institute, the PNG University of Technology, the Vision 2050 (long-term planning) branch of the Prime Minister's Department, and one of the local NGOs that are affiliated with the PNG Eco-Forestry Forum. Most of the individuals in this group do not hail from East Sepik Province, but one thing they had in common was their opposition to Kevin Conrad's control of the forest carbon policy process. Beyond that, they had a lukewarm relationship with the big international NGOs that had taken an interest in this process, despite (or possibly because) some of them were previously employed by these organisations. This might help to explain why WWF did not show much enthusiasm for the ASSFMP, even when foreigners like Stephen Hooper tried to gain its endorsement. As we have seen, the pursuit of 'additionality' entailed an attack on the validity of the WMA which WWF had previously tried to establish as a defence against the prospect of logging, but there was also a kind of resource nationalism at work in claims to ownership of April Salumei. In this respect, she became a stage from which her national supporters sought to fill the vacant space that Conrad should have left behind him.

It is hard to say whether the factors that explain the relative success of the April Salumei project to date will explain its continued success in future, or whether its further development will serve to clarify the relative importance of these different factors. It seems unlikely that this project alone will generate significant revenues if no further progress is made with the national 'roadmap' whose engineering is still vested in the OCC, but progress has been rather slow. In the two years after the UN Collaborative Programme agreed to spend US\$6.4 million on PNG's roadmap, the OCC only managed to produce a second draft of its Climate Compatible Development Policy (GPNG 2013a), a working draft of a Readiness Preparation Proposal (GPNG 2013b), and a draft bill for a Climate Change Authority Act. It managed to finalise a set of guidelines and an institutional framework for the official approval of REDD+ projects (GPNG 2012 b), including draft guidelines for securing free, prior and informed consent for such projects (GPNG 2013c), but it is not clear whether the April Salumei project has passed through this approval process or whether its endorsement 
by the PNGFA and the National Executive Council has itself been counted as sufficient evidence of government authorisation. The Readiness Preparation Proposal says that project activities in the area 'will be determined after a development option study' (GPNG 2013b: 60). This is a type of study undertaken under the terms of the Forestry Act, and if another one is undertaken, it will be the third or fourth to be undertaken since the timber harvesting rights were first acquired by the state in 1992. The local landowners may have to wait a while longer for their carbon credits to be realised.

\section{Acknowledgements}

Thanks to Andrea Babon, Paul Chatterton, Stephen Hooper, Matt Leggett, Dave Melick, Rune Paulsen, James Sabi, Gwen Sissiou and Mike Wood for comments and information. None of them bears any responsibility for the argument contained in the paper.

\section{References}

Anderson, P., 2011. 'Free, Prior and Informed Consent in REDD+: Principles and Approaches for Policy and Project Development.' Bangkok: RECOFTC (The Center for People and Forests).

Anon., 2004. 'MP Aimo Gets Behind April-Salumei Project.' The National, 30 January.

Anon., 2008. 'Carbon Trading or Carpet Baggers.' Post-Courier, 22 November.

Anon., 2009a. 'Aihi Urges PM to Launch Probe into Climate Change Office.' The National, 9 June.

Anon., 2009b. 'Yasause Slams Media Report.' The National, 9 June.

Anon., 2009c. 'Group Awaits K500,000.' The National, 9 July.

Anon., 2011. 'Big Sister's Carbon Tax, a Catalyst for Carbon Cowboys?' The Masalai Blog, 28 August.

Anon., 2012a. 'HRH Meets on Forestry.' Post-Courier, 13 November.

Anon., 2012b. 'Forest Owners Ready to Benefit.' The National, 6 December.

Babon, A., 2011. 'Snapshot of REDD+ in Papua New Guinea.' Bogor: Center for International Forestry Research (Infobrief 40). 
Babon, A., D. McIntyre, G.Y. Gowae, C. Gallemore, R. Carmenta, M. Di Gregorio and M. Brockhaus, 2014. 'Advocacy Coalitions, REDD+, and Forest Governance in Papua New Guinea: How Likely Is Transformational Change?' Ecology and Society 19(3): 16.

Bamu, S., 2005. 'Carbon Swap Has a Bad Smell.' Post-Courier, 20 June.

Callick, R., 2009. 'The Rush Is On for Sky Money: The Struggle Begins to Control the Immense Wealth Certain to Flow from Carbon Trading.' Weekend Australian, 5 September.

Callick, R. and I. Gridneff, 2009. 'Rush Is On for "Sky Money".' Post-Courier, 10 September.

CCBA (Climate, Community and Biodiversity Alliance), 2010. 'April Salumei Sustainable Forest Management Project: Comments Received by the CCBA During the Validation Audit.' Arlington (VA): CCBA.

Chem-Clean Ltd, 2009. 'April-Salumei Pilot Reduce Emissions from Deforestation and Degradation (REDD) Project Initial Stakeholder Consultation Report.' Unpublished report to PNG Office of Climate Change and Environmental Sustainability.

Chem-Clean Ltd, University of PNG and South Pole Carbon Asset Management Ltd, 2009. 'April Salome Sustainable Forest Management Project: First Stakeholder Consultation Report.' Unpublished report.

Duguman, J., 2004. 'Review of the Sepik Community Land Care Project.' Unpublished report to World Wide Fund for Nature.

Earthsky Ltd, 2008. 'Project Design Document: April Salome Sustainable Forest Management.' Unpublished draft report to Voluntary Carbon Standard.

Filer, C., 2005. 'The Conservation Policy Community in Papua New Guinea.' Canberra: The Australian National University, Resource Management in Asia-Pacific Program (Working Paper 55).

Filer, C., 2012. 'Why Green Grabs Don't Work in Papua New Guinea.' Journal of Peasant Studies 39(2): 599-617.

Filer, C. and M. Wood, 2012. 'The Creation and Dissolution of Private Property in Forest Carbon: A Case Study from Papua New Guinea.' Human Ecology 40(5): 665-77.

GPNG (Government of Papua New Guinea), 2001. 'April Salumei (East Sepik Province).' Port Moresby: PNG Independent Forestry Review Team (Individual Project Review Report 25). 
GPNG (Government of Papua New Guinea), 2009. 'Transcript of Proceedings, Wednesday 8 July 2009.' Port Moresby: Commission of Inquiry into the Department of Finance.

GPNG (Government of Papua New Guinea), 2012a. 'National Forest Plan' (draft). Port Moresby: PNG Forest Authority.

GPNG (Government of Papua New Guinea), 2012b. 'National REDD+ Project Guidelines.' Port Moresby: Office of Climate Change and Development.

GPNG (Government of Papua New Guinea), 2013a. 'Climate Compatible Development Policy 2013-2015.' Port Moresby: Office of Climate Change and Development.

GPNG (Government of Papua New Guinea), 2013b. 'Readiness Preparation Proposal (R-PP) - Version 11: Final Working Draft.' Port Moresby: Office of Climate Change and Development.

GPNG (Government of Papua New Guinea), 2013c. 'Revised Draft Guidelines on Free, Prior and Informed Consent for REDD+ in Papua New Guinea.' Port Moresby: Office of Climate Change and Development.

Green, C., 2012. 'April Salumei Sustainable Forest Management Project: VCS Feasibility Assessment.' Report to Pacific Forest Alliance Ltd.

Gridneff, I., 2009a. ' "Sky Money" Carbon Scheme a Hoax.' The National, 15 June.

Gridneff, I., 2009b. 'Aust Company Caught in PNG Carbon Fiasco.' Post-Courier, 31 July.

Guddemi, P., 1997. 'Continuities, Contexts, Complexities, and Transformations: Local Land Concepts of a Sepik People Affected by Mining Exploration.' Anthropological Forum 7(4): 629-648.

Hooper, S., C. Kaluwin, J. Duguman, G. Gowae, A. Asmann, E. Kwa, O. Gideon and S. Saulei, 2011. 'Project Design Document: April Salumei, East Sepik, Papua New Guinea.' Arlington (VA): Climate, Community and Biodiversity Alliance.

Howes, S., 2009. 'Cheap But Not Easy: The Reduction of Greenhouse Gas Emissions from Deforestation and Forest Degradation in Papua New Guinea.' Pacific Economic Bulletin 24(1), 130-43.

Lang, C., 2009a. 'Anatomy of a Deal: The April Salome REDD Project in Papua New Guinea.' REDD-Monitor, 7 June. 
Lang, C., 2009b. 'Kevin Conrad on REDD, Irregularities and Carbon Cowboys in PNG.' REDD-Monitor, 9 July.

Lang, C., 2010a. 'Forests, Carbon Markets and Hot Air: Why the Carbon Stored in Forests Should Not Be Traded.' REDD-Monitor, 11 January.

Lang, C., 2010b. 'McKinsey's REDD Plans in Papua New Guinea: Nice Work If You Can Get It.' REDD-Monitor, 7 October.

Leggett, M., 2009. 'Selim Win Bilong Yumi': The Social Dimensions of Carbon Forestry in Papua New Guinea. Edinburgh: University of Edinburgh (MA thesis).

Leggett, M. and H. Lovell, 2012. 'Community Perceptions of REDD+: A Case Study from Papua New Guinea.' Climate Policy 12(1): 115-34.

Melick, D., 2008. 'On-the-Ground Role of NGOs with Emerging Carbon Market Issues: Is the REDD Emperor Actually Wearing Any Clothes?' Paper presented to seminar on 'Challenges to the National Implementation of Activities to Reduce Emissions from Deforestation and Forest Degradation (REDD)', The Australian National University, Canberra, 18 June.

Melick, D., 2010. 'Credibility of REDD and Experiences from Papua New Guinea.' Conservation Biology 24(2): 359-61.

Morauta, M., 2009. 'Carbon Trading and Office of Climate Change and Environment Sustainability.' The National, 20 July.

OCCCT (Office of Climate Change and Carbon Trade), 2009. 'Call for Stakeholder Comments and Invitation for the Meeting.' Post-Courier, 30 April.

OCCD (Office of Climate Change and Development), 2010. 'Voluntary Carbon Projects.' Post-Courier, 14 July.

OCCES (Office of Climate Change and Environmental Sustainability), 2009. 'Voluntary Carbon Agreements (VCA) Are Not Currently Supported by the Government.' Post-Courier, 2 September.

Pearse, R., 2012. 'Mapping REDD in the Asia-Pacific: Governance, Marketisation and Contention.' Ephemera 12(1/2): 181-205.

PFA (Pacific Forest Alliance Ltd), 2012. 'April Salumei Rainforest Preservation Project: April Salumei CCB Monitoring Plan.' Arlington (VA): Climate, Community and Biodiversity Alliance.

Power, T., 2004. 'Timber Project Facts.' The National, 9 February. 
RPM (Rainforest Project Management Ltd), 2010. 'Project Design Document: April Salumei, East Sepik, Papua New Guinea.' Unpublished draft report to Climate, Community \& Biodiversity Alliance.

SCS (Scientific Certification Systems), 2011. 'Final CCBA Project Validation Report: April Salumei, East Sepik, Papua New Guinea.' Arlington (VA): Climate, Community and Biodiversity Alliance.

Somare, M., 2009. 'Carbon Trading and Office of Climate Change and Environmental Sustainability.' Post-Courier, 3 August.

Talu, P., 2009. 'PM Under Fire Over K547mil Payment.' The National, 4 September.

UN-REDD (United Nations Collaborative Programme on Reducing Emissions from Deforestation and Forest Degradation in Developing Countries), 2011. 'National Programme Document: Papua New Guinea.' Port Moresby: UN-REDD.

Waima, K., 2011. 'Climate Change Ambassador in US to Be Replaced.' PostCourier, 18 August.

Wynn, G. and S. Creagh, 2009. 'Forest Carbon Market Already Shows Cracks.' Post-Courier, 9 June. 
This text is taken from Tropical Forests of Oceania: Anthropological Perspectives, edited by Joshua A. Bell, Paige West and Colin Filer, published 2015 by ANU Press, The Australian National University, Canberra, Australia. 